\title{
Morphology and phytogeography of Laminaria appressirhiza and L. inclinatorhiza (Phaeophyceae) from the Sea of Okhotsk
}

\author{
Tatyana A. Klochkova ${ }^{1}$, Gwang Hoon Kim ${ }^{1}$, Mihail N. Belij ${ }^{2}$ and Nina G. Klochkova ${ }^{3, *}$ \\ ${ }^{1}$ Department of Biology, Kongju National University, Kongju 314-701, Korea \\ ${ }^{2}$ Magadan Scientific-Research Institute of Fishery and Oceanography (MagadanNIRO), Magadan, Portovaya 36/10, \\ 685014, Russia \\ ${ }^{3}$ Kamchatka State Technical University (KamchatGTU), Petropavlovsk-Kamchatsky, Klyuchevskaya 35, 683003, Russia
}

\begin{abstract}
The re-examination of morphological and anatomical characters of Laminaria appressirhiza and L. inclinatorhiza collected from different localities in the Sea of Okhotsk was performed. Despite their commercial and ecological importance to the region they have not been comprehensively reviewed since their first description in 1970. Our results show that some original diagnostic key characters (e.g., shape of holdfast, shape of sporangial sori, and dissection of blade) are not stable and have deviations from the type morphology when plants grow in different environments. In L. inclinatorhiza, the sporangial sori development occurred differently to the pattern indicated in original species description as they did not develop simultaneously on both sides of the blade. Instead, the sporangial sori outlines on both sides of the blade did not coincide at first and only became coincident later. Also, a deep-water population of $L$. inclinatorhiza with an unusual and interesting morphology, growing at depths of 15-25 m on opened rocky coasts in Taujskaya Bay (northern part of the Sea of Okhotsk) was found. The stable diagnostic key characters to distinguish these two species are the cone-like, multilayered, very thick and massive holdfast (in L. inclinatorhiza) and rolled margins of blades, lamellar rosette-like part of thallus, and sporangial sori developing only on one side of the blade (in L. appressirhiza). The ecological characteristics, distribution, and abundance of both species in the Sea of Okhotsk are discussed. Both species are perennial and widely distributed in the region. L. appressirhiza is more often found as a subdominant species among other kelps, forming maximum biomass and density of 7-9 $\mathrm{kg}$ and 8-25 plants per $1 \mathrm{~m}^{2}$, respectively. L. inclinatorhiza sometimes forms local mono-species communities with maximum biomass and density of 10-12 $\mathrm{kg}$ and $10-15$ plants per $1 \mathrm{~m}^{2}$, respectively.
\end{abstract}

Key Words: Endemic species; Flora; Laminaria appressirhiza; Laminaria inclinatorhiza; Sea of Okhotsk

\section{INTRODUCTION}

Kelp forests are the most important components of the ecosystems of temperate and polar rocky shores. They ensure high productivity, biodiversity, and healthy ecological condition of the marine biota and they constitute habitat and breeding grounds for a large diversity of marine life forms (Klochkova et al. 2009, Belij 2011, Zambou- nis et al. 2012). Regarding the diversity and natural stocks of various marine organisms, including the macroalgae, the Russian Far East represents one of the richest regions of the world. However, due to geographical and historical reasons it remains one of the least studied areas. The extensive coastline of the Russian Far Eastern region is (c) This is an Open Access article distributed under the terms of the Creative Commons Attribution Non-Commercial License (http://creativecommons.org/licenses/by-nc/3.0/) which permits unrestricted non-commercial use, distribution, and reproduction in any medium, provided the original work is properly cited.
Received April 10, 2012, Accepted July 16, 2012

*Corresponding Author

E-mail:ninakl@mail.ru

Tel: +7-4152-300929, Fax: +7-4152-420501 
mostly unpopulated and inaccessible, which makes field collections very difficult, one example being the northern areas of the Sea of Okhotsk. Recently, a renewed interest in the macroalgal ecosystems in this region has arisen (e.g., Klochkova et al. 2010, 2012) because of the economic development and fishery demands in the area (Belij 2011). In this region, the laminariaceaen algae are dominant or co-dominant members of macrophytobenthic communities in the littoral and sub-littoral zones. Three digitate species of Laminaria sensu Lamouroux were recorded from the Sea of Okhotsk, including L. appressirhiza Petrov et Vozzhinskaja, L. inclinatorhiza Petrov et Vozzhinskaja, and L. yezoensis Miyabe (Klochkova and Berezovskaya 1997). Among them, L. appressirhiza and L. inclinatorhiza are known as regional endemics with limited distribution in the Sea of Okhotsk, growing in the lower horizons of the phytal zones, at depths of 10-18 m, where the seawater temperature is consistently low.

The species L. digitata (Hudson) Lamouroux, a commercially important seaweed putatively widely distributed over three continents, has been reported from many European countries, Arctic regions, eastern North America and even from the southern Atlantic in Namibia and South Africa (Guiry and Guiry 2012). It has also been reported from the Sea of Okhotsk for a long time (e.g., Ruprecht 1850, Schapova 1948, Sinova 1954, Vozzhinskaja 1965, Blinova 1968). However, upon careful investigation of the morphology of all existing specimens collected from the Sea of Okhotsk, Petrov and Vozzhinskaja (1970) reported that those specimens were misidentified as $L$. digitata. Therefore, they established two new species, $L$. appressirhiza and L. inclinatorhiza, emphasizing the distinct shapes of their holdfasts (appressed and tapered, respectively) as one of the diagnostic morphological features. Another feature emphasized difference in the pattern of sporangial sori development. Although described in sufficient details, the original paper contained only black and white photos of the dried type specimens, and these did not show many details (i.e., specific shape of blade and holdfast, sporangial tissue, haptera structure, etc.). Moreover, the morphological key characters were not subjected to confirmation for over 40 years. Bartsch et al. (2008) stated that these species are unknown to a majority of foreign phycologists and need re-examination. In this study, we re-examined the morphological characters of L. appressirhiza and L. inclinatorhiza collected from different localities in the Sea of Okhotsk and compared our samples to the type specimens discussed by Petrov and Vozzhinskaja (1970). We also provide data on the eco- logical characteristics of these species including local distribution and abundance in the Sea of Okhotsk.

\section{MATERIALS AND METHODS}

\section{Sample collection and specimen observation}

Type specimens of L. appressirhiza and L. inclinatorhiza, which are currently kept in the Komarov Botanical Institute of Russian Academy of Sciences (LE, St. Petersburg, Russia) were observed (Fig. 1) and compared with our samples.

During the course of this study, we observed numerous freshly collected specimens of L. appressirhiza, L. digita$t a$, and L. inclinatorhiza. The information for specimens used for the illustrations in Figs 2-6 is listed in Table 1. Specimens of L. appressirhiza and L. inclinatorhiza were mostly collected by the authors N. G. K. and M. N. B. The author M. N. B. explored various northern localities of the Sea of Okhotsk for many years by SCUBA-diving, conducting underwater algal collections in different seasons of the year and gathering abundant kelp samples and underwater photographs (Belij 2011). Another author (N. G. K.) participated in several hydrobiological expeditions in the Sea of Okhotsk and on the western coast of Kamchatka.

Specimens of $L$. digitata were collected from $\mathrm{Ny}-$ Álesund, Svalbard (Kongsfjorden), in June 2009 by the authors G. H. K. and T. A. K. Also, dry specimens of L. digitata from the White Sea collected by A. D. Zinova (Jul 30,1938), F. J. Ruprecht (collection date unknown), K. K. Sent-Iler (Jul 20,1921), and E. S. Sinova (collection year 1916) held in the Komarov Botanical Institute (LE, St. Petersburg, Russia) were observed. Collections of dry specimens of Russian laminariaceaen algae kept in TINRO-center (Vladivostok, Russia) and Kamchatka State Technical University (KamchatGTU, Russia) were also studied. Voucher specimens of L. digitata from $\mathrm{Ny}$-Álesund are held in Kongju National University (KNU) and L. appressirhiza and L. inclinatorhiza are held in KamchatGTU and KNU.

For microscopic observations, a dry piece of thallus was re-hydrated in sterilized seawater, cut with a fine razor blade, and observed under a microscope. Micrographs were taken with Olympus DP50 digital camera (Olympus, Tokyo, Japan) affixed to an Olympus BX50 microscope using Viewfinder Lite and Studio Lite computer programs. 

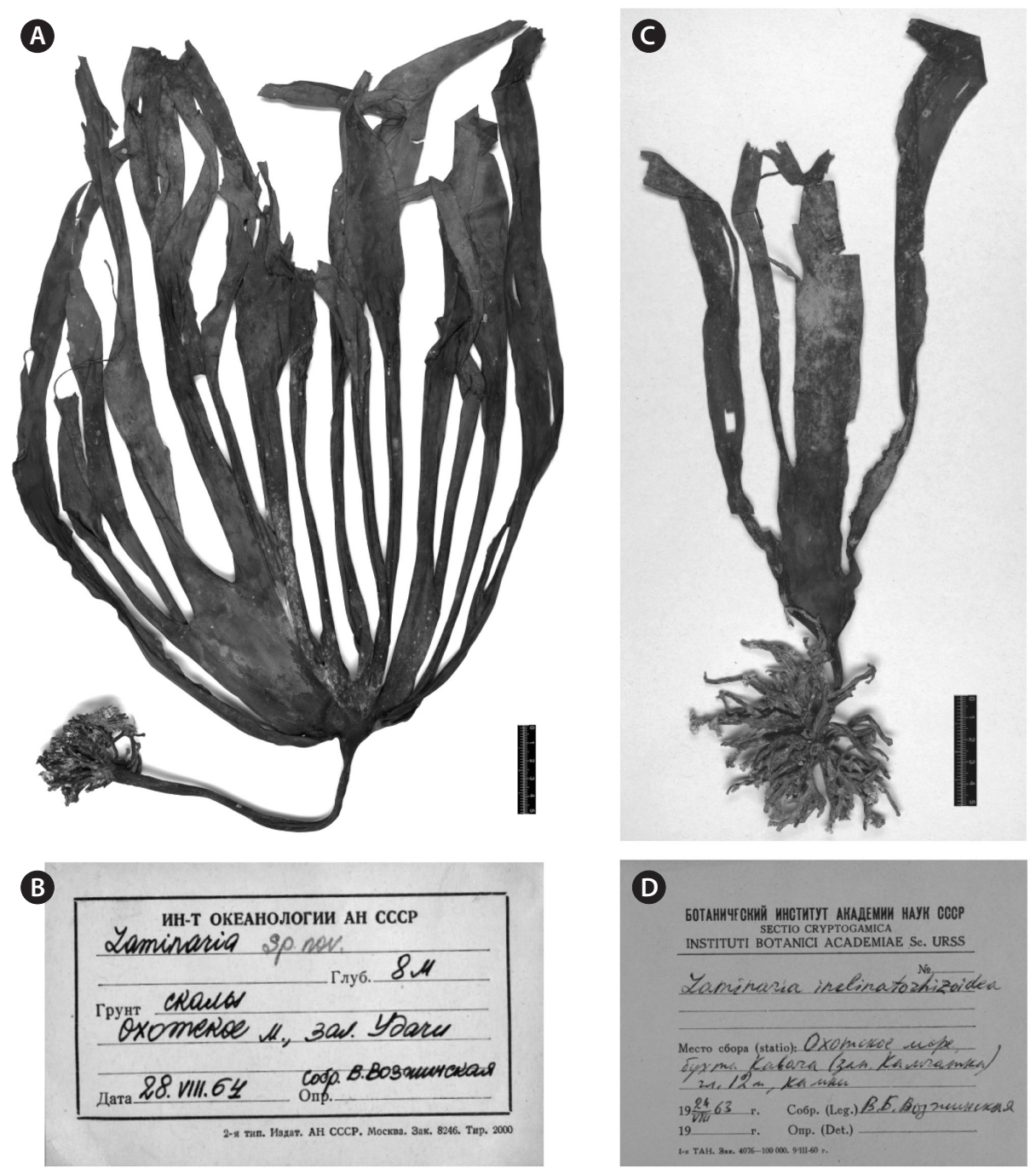

Fig. 1. Type specimens of Laminaria appressirhiza (A \& B) and L. inclinatorhiza (C \& D) and original labels (photographed in April 2012). Black and white photos of these specimens were also displayed in Novosti Sistematiki Nizshih Rastenii (News on Systematics of Non-vascular Plants) by Petrov and Vozzhinskaja (1970). Scale bars represent: A \& C, $5 \mathrm{~cm}$.

Table 1. Specimens used for the demonstrations of the distinctive morphologies of species in present study, their collection site and date

\begin{tabular}{lcc}
\hline Species & Collecting site and date & Voucher specimen No. \\
\hline Laminaria appressirhiza & Taujskaya Bay, Sea of Okhotsk, Russia; Jul 14, 2008 & CH2208 \\
& (2-year-old plants, cast ashore and SCUBA diving; & CH2209 \\
& Coll. by N. G. Klochkova \& M. N. Belij) & KNU-NÁ2009 \\
L. digitata & Ny-Álesund, Svalbard; Jun 15-21, 2009 (1- \& 2-year- & \\
& old plants, cast ashore; Coll. by G. H. Kim \& T. A. & CH2206 \\
Klochkova) & CH2207 \\
CH2206-Taujskaya Bay, Sea of Okhotsk, Russia; & \\
& Jul 15, 2008 (1- \& 2-year-old plants, deep-water, & \\
& SCUBA diving; Coll. by M. N. Belij) & \\
& CH2207-Taujskaya Bay, Sea of Okhotsk, Russia; & \\
& Jul 14, 2008 (2-year-old plant, cast ashore; Coll. by & \\
\hline
\end{tabular}



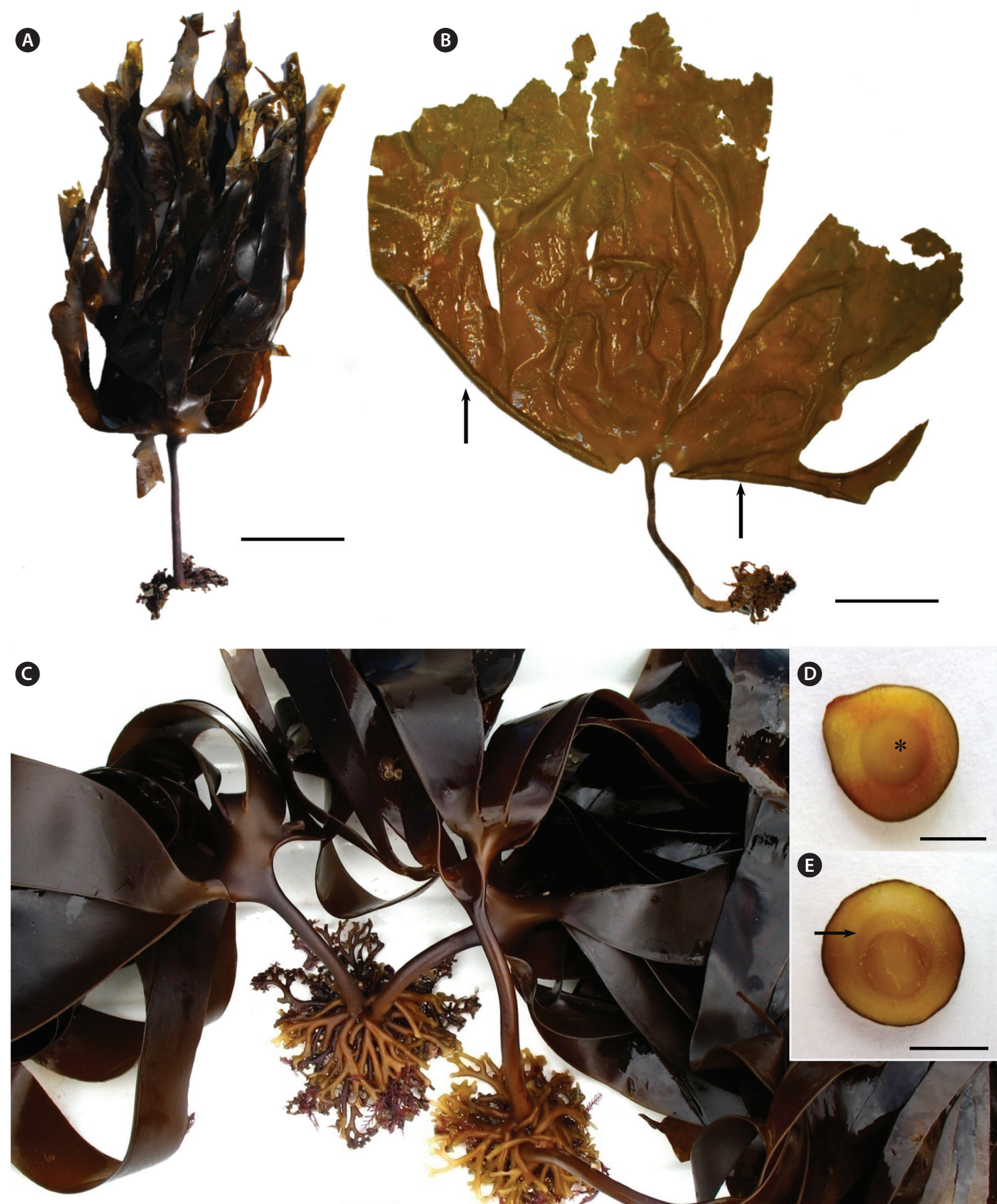

E
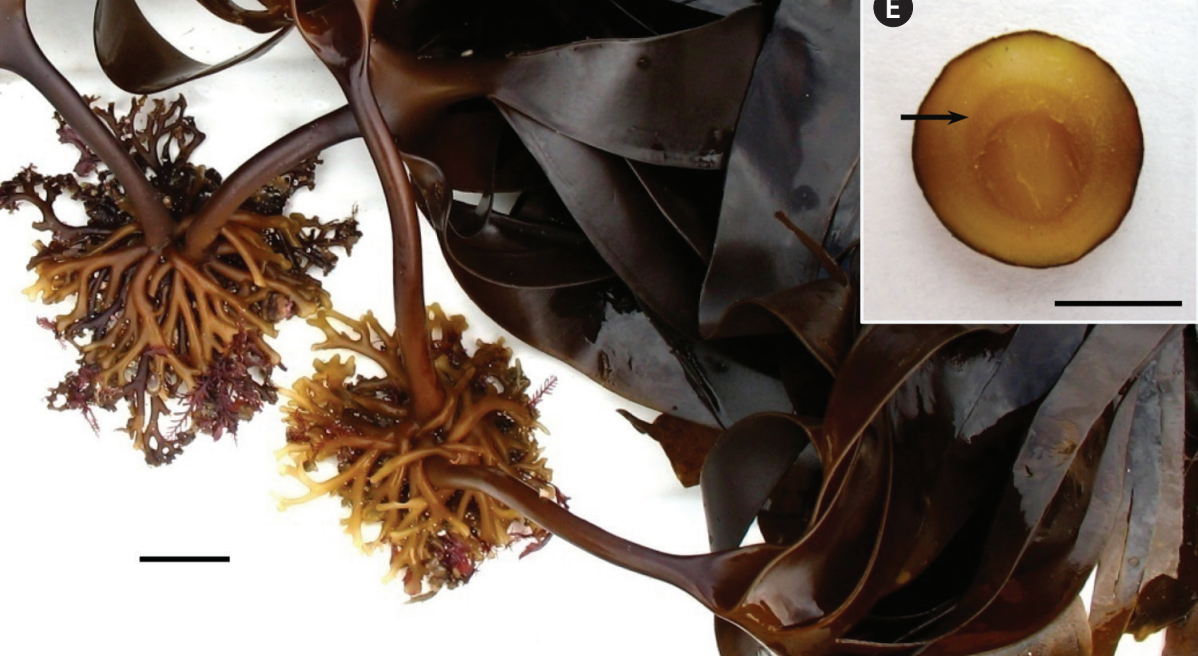

Fig. 2. Laminaria appressirhiza. (A) Representative of dissected plants collected from Taujskaya Bay (vouchers $\mathrm{CH} 2208, \mathrm{CH} 2209$, $\mathrm{CH} 2210$ ). (B) Less dissected plant, showing typical rolled margins of blade when slightly dried (arrows). (C) Morphology of stipe and holdfast. (D \& E) Horizontal cross-sections cut through the stipes of 1-year-old (D) and 2-year-old (E) plants. For the estimation of plant age, we counted the number of annual rings (arrow) and analyzed overall plant morphology. The medullar layer is marked with asterisk. Scale bars represent: $A$ \& B, $20 \mathrm{~cm} ; C, 3 \mathrm{~cm} ; D$ \& , $5 \mathrm{~mm}$. 


\section{RESULTS}

\section{Original diagnosis of Laminaria appressirhiza by Petrov and Vozzhinskaja (1970)}

The blade is roundish or oval, dissected, up to 500-1,000 $\mathrm{mm}$ long. Freshly-collected blade is rolled into a tube; in nature often looking like a rosette with widely spreading fronds. Stipe is erect, about $10 \mathrm{~mm}$ in diameter and 150$280 \mathrm{~mm}$ long; in plants collected from littoral zone stipe can be up to $40 \mathrm{~mm}$ long. Holdfast originate from the stipe at almost right angle; haptera are rigid, branch multiple times (at each $10 \mathrm{~mm}$ ), becoming thinner toward the tips. In cross-section, the medullar part of the blade occupies from 17 to $40-60 \%$ of its thickness. Mucilage ducts are quite large, $40-56 \times 80-100 \mu \mathrm{m}$, located at a distance of 250-350 $\mu \mathrm{m}$ from each other. The distance from the outer surface of blade to the center of mucilage duct and then to the blade's medullar layer is $1: 1.5-1: 2.5$. Mucilage ducts are absent from the stipe and haptera. Sporangia develop in August-September only on one side of the blade, facing outward. Thus, the herbarium specimens have rolled margins of blades in places of sporangial sori localization.

Type (Fig. 1A \& B). Sea of Okhotsk, Gizhinskaya Bay, Udachi Inlet, depth 8 m, Aug 28, 1964, collected by V. B. Vozzhinskaja. Kept in Botanical Institute of Russian Acad. Sci., Leningrad (LE, St. Petersburg).

\section{Original diagnosis of Laminaria inclinatorhiza by Petrov and Vozzhinskaja (1970)}

Blade is roundish, elongated-elliptical or ovate, dissected or non-dissected (in wave-sheltered areas near Shantar Islands), flattened or concave at its base, up to $740 \mathrm{~mm}$ long. Stipe is erect, about $10 \mathrm{~mm}$ in diameter and 30-70 mm long. Haptera are loosely branched; holdfast forms a big cone, which is almost as long as the stipe. Holdfast originate at an angle from the stipe and haptera begin to branch only in the lower portion; often they do not branch for the first $40 \mathrm{~mm}$ from the stipe. Haptera reach maximum width (5.5-6 mm) and thickness (up to $4.2 \mathrm{~mm}$ ) in the middle part, but they are narrower (up to $2.7 \mathrm{~mm}$ ) where they originate from the stipe. Whole holdfast can be easily broken from the stipe, especially in herbarium specimens. In cross-section, the medullar part of blade occupies about $22 \%$ of its thickness. In the blade, the mucilage ducts are ca. $80-120 \mu \mathrm{m}$ in size, located at a distance of 20-180 $\mu \mathrm{m}$ from each other. The distance from the outer surface of blade to the center of mucilage duct and then to the blade's medullar layer is $1: 2.1-1: 2.5$. In stipe and haptera, mucilage ducts are absent. Sporangia develop in late July-September on both sides of the blade, the sporangial outlines coincide in shape.

Type (Fig. 1C \& D). Sea of Okhotsk, Kavacha Bay (northwest Kamchatka), depth 12 m, Aug 24, 1963, collected by V. B. Vozzhinskaja. Kept in Botanical Institute of Russian Acad. Sci., Leningrad (LE, St. Petersburg).

\section{Observations of morphology by present authors}

The following descriptions are based on our personal observations of collected samples. Morphologically, $L$. appressirhiza (Figs 2, 3A-D \& 6A-C) and L. inclinatorhiza (Figs 4-6D \& E) are distinct from each other and from $L$. digitata (Fig. 3E \& F).

\section{Laminaria appressirhiza}

The stipe is elastic, cartilaginous, cylindrical, 15-30 cm long, ca. 1-1.5 cm in diameter, olive, yellow-brown or dark-brown in color, darker in its upper part (Fig. 2CE). Haptera (Fig. 2A \& C) are rigid, cartilaginous, relatively thick, dichotomously or irregularly dichotomously branched, slightly broadening where they branch and becoming thinner to the tips. Young holdfast is light yellow-brown or olive in color, whereas old holdfast is dark-brown or black-brown. In cross-section, the color of the medullar layer is not different from the color of the next layer in both young (Fig. 2D) and old plants (Fig. 2E). Holdfast most often originates from the stipes at almost right angle. In plants growing on cobble, it originates from the stipes at an acute angle.

The blade is roundish or oval in shape (Fig. 3C \& D), up to $1 \mathrm{~m}$ in length and ca. $1 \mathrm{~m}$ in width or even wider (Fig. 2A \& B), dark-olive, brown or reddish-brown in color, without bullation at any age. In cross-section, the young blade is ca. $430 \mu \mathrm{m}$ thick; the medullar part occupies from 15 to $18 \%$ of its thickness. In fertile plants, the blade is ca. $600 \mu \mathrm{m}$ thick and the medullar part occupies ca. $27.5 \%$ of its thickness (Fig. 6C). At the beginning of linear growth, both young and older plants have an unsplit and more or less concave blade. During subsequent growth, the blade becomes more concave, thus resulting in formation of its funneled basis. Then the longitudinal splits occur. The number of straplike blades vary with the amount of exposure to waves and the lacerations extend almost to the base of the blade. Sometimes, the lacerations are so deep that even the stipe splits. Old blades can have 15-30 straps of 3-5 cm at width. Thus the lamellar part of thallus often looks like a rosette with straplike blades spreading radi- 


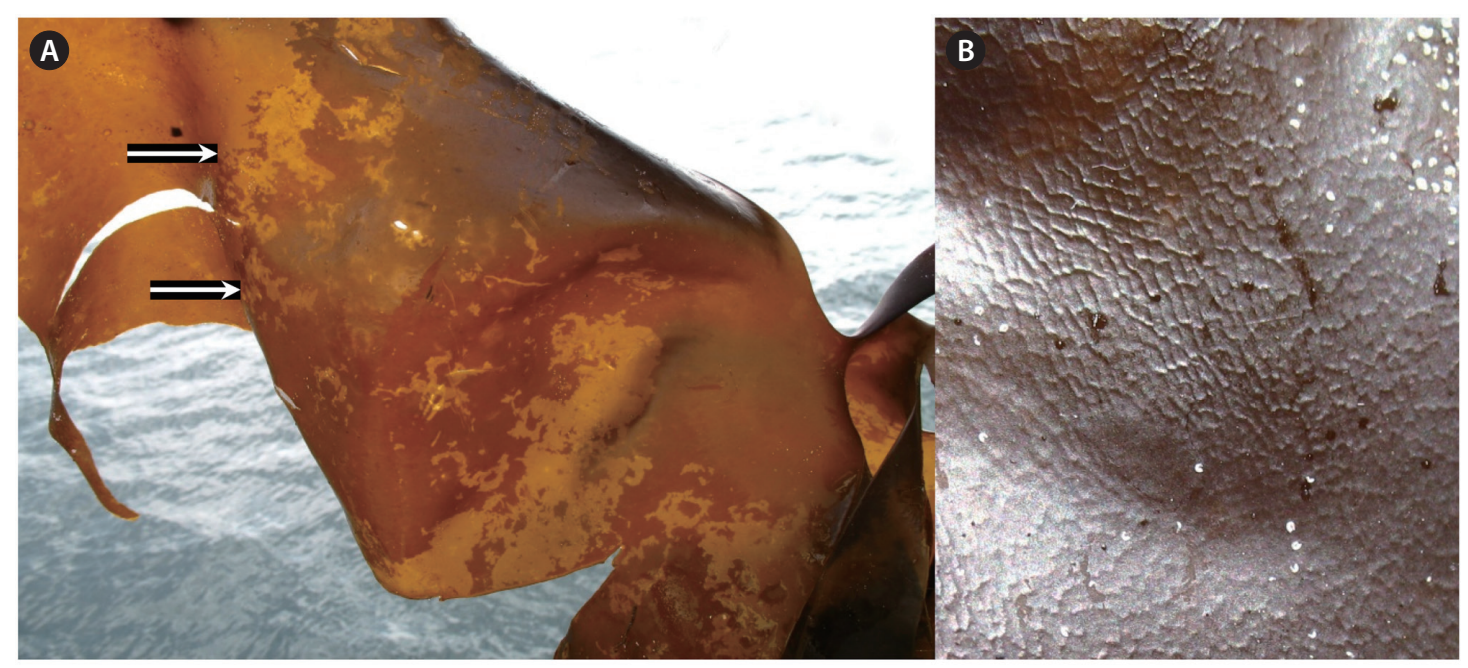

C
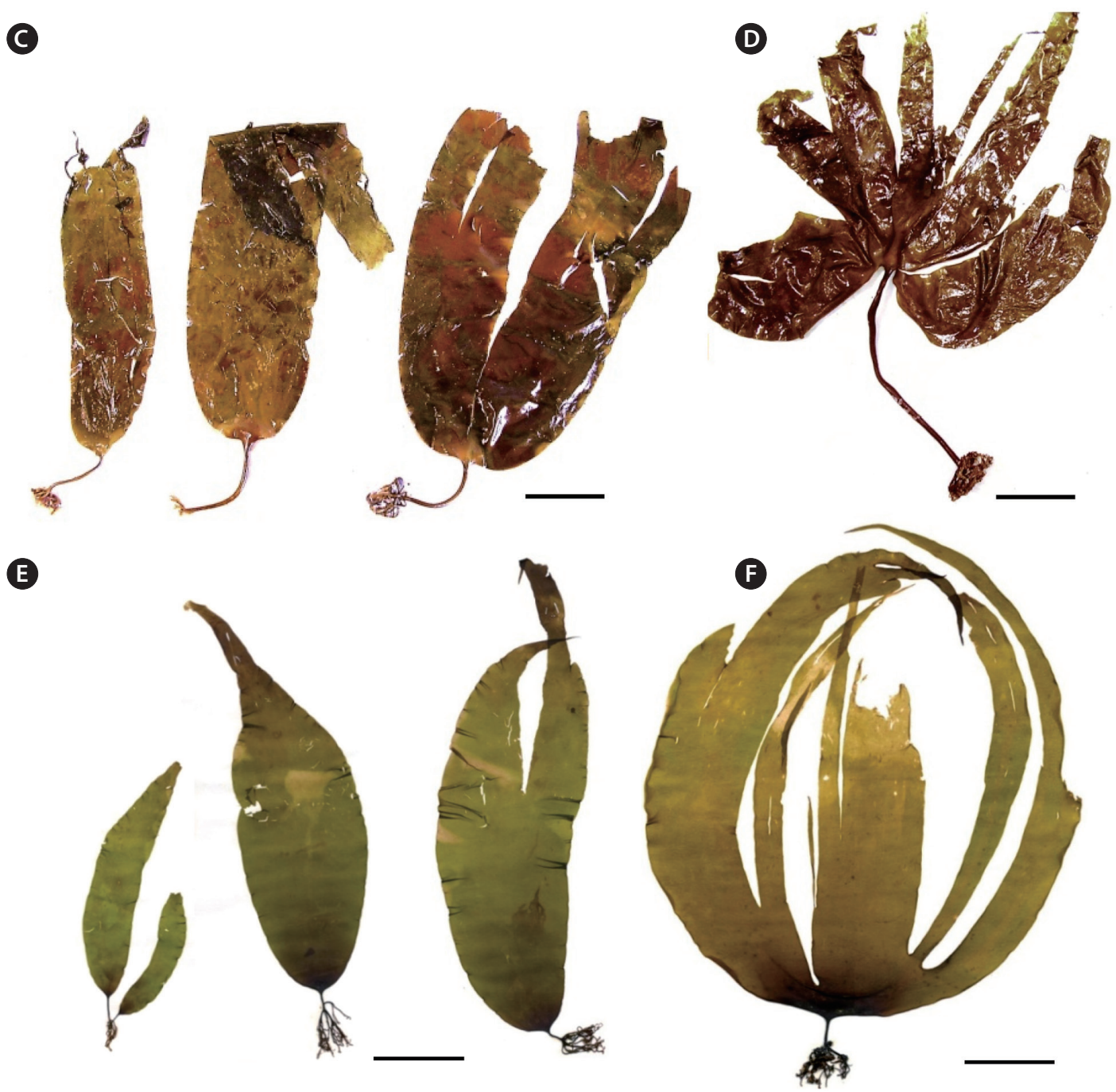

Fig. 3. Laminaria appressirhiza (A-D) and L. digitata (E \& F). (A) Development of sporangial sori (darker colored part of blade, arrows point to the outlines) normally occurs in the lower part of the blade. (B) The network of mucilage ducts beneath the cortex layer seen from the outer surface. (C-F) Plants of L. appressirhiza (C \& D) and L. digitata (E \& F, voucher KNU-NÁ2009) at different developmental stages. Note that after the stage of linear growth (C \& E), in the older plants of L. appressirhiza the straps spread in radial direction (D), but in L. digitata the blade is more elongateelliptical in shape (F). Scale bars represent: C \& D, $10 \mathrm{~cm}$; E \& F, $5 \mathrm{~cm}$. 
ally. Sporangial sori develop more often on one side of the blade in its lower part (Fig. 3A) in late July-September. In partially and completely dried adult plants, the margins of straps are almost always rolled into a tube, even when the plants are not fertile (Fig. 2B). In young plants not bearing sporangial sori, the mucilage ducts are smaller (40-50 $\mu \mathrm{m}$ in size) and appear on both sides of the blade; however, they are more pronounced on one side of the blade than on the another. In some blades, the network of mucilage ducts beneath the cortex layer could be seen even from the outer surface (Fig. 3B). In fertile plants, the mucilage ducts are large (up to $109 \mu \mathrm{m}$ in size) and appear only on one side of the blade that does not have sporangial sori. Mature unilocular sporangia are ca. $51 \mu \mathrm{m}$ in length (Fig. 6A). Paraphyses are 77-96 $\mu \mathrm{m}$ long, narrower at the distal end (Fig. 6B).

L. appressirhiza is perennial and widely distributed in the Sea of Okhotsk, growing on rocks and stones at depths of 5-15 (18) $\mathrm{m}$ in places with moderate or strong waves. It is more often found as subdominant species among other kelps. The maximum biomass is $7-9 \mathrm{~kg}$ per $1 \mathrm{~m}^{2}$ and density 8-25 plants per $1 \mathrm{~m}^{2}$. In some coastal areas it forms mono-species algal beds or narrow bands, or is mixed with L. inclinatorhiza.

Specimens observed in present study. Continental coast of the Sea of Okhotsk, Taujskaya Bay, collected by N. G. Klochkova and M. N. Belij on Jul 14-15, 2008 (vouchers CH2208, CH2209, CH2210). Western Kamchatka, UstHajryuzovo village and Ptichij Island, collected by N. G. Klochkova and A. A. Emelyanova on Jul 25-26, 2004 (specimens illustrated by Klochkova et al. 2009).

\section{Laminaria inclinatorhiza}

During the present study we observed that the key characters listed by Petrov and Vozzhinskaja (1970) do not always precisely apply to the morphology of L. inclinatorhiza. The plants from different localities (vouchers CH2206, CH2207) had obvious morphological differences from the type specimens.

Specimens observed in present study. Continental coast of the Sea of Okhotsk, Taujskaya Bay, collected by N. G. Klochkova and M. N. Belij on Jul 14-15, 2008. Western Kamchatka, Ust-Hajryuzovo village and Ptichij Island, collected by N. G. Klochkova and A. A. Emelyanova on Jul 25-26, 2004 (specimens illustrated by Klochkova et al. 2009).

\section{Description of typical morphology of Laminaria inclinatorhiza (voucher CH2207)}

During our field studies, we often collected plants with morphology fitting the description and illustrations of Petrov and Vozzhinskaja (1970) from the shallow waveswept waters (Fig. 4A \& B). Young blades can be entire, roundish or elongate-elliptical in shape. In younger plants, the blades are slightly concave, resembling a hood; however they later tend to become broader and roundish. In older plants the blades are up to $1 \mathrm{~m}$ in length, very dissected, having 2-3 or up to 10-12 straplike blades in younger and older thalli, respectively, each being 1 to 5-8 $\mathrm{cm}$ in width. The lacerations extend almost to the base of the blade. The blades are quite fragile and easily detachable from the stipe, thus we often found holdfasts without blades on the substrate (Fig. 4A \& I). Bullation is not observed at any age and the blade's margins are never rolled such as in L. appressirhiza. The stipe is elastic, cylindrical, often slightly broadened in its middle part, from 6-8 to $45 \mathrm{~cm}$ long, 1-1.5 cm in diameter, olive, yellow-brown, or dark-brown in color, sometimes flattened in the upper $1 / 3$ of its length. Holdfast is tapered, shaped like a cone in cross-section; haptera are rigid, cartilaginous, very thick, irregularly dichotomously branched, becomming narrower at the tips (Fig. 4I). Young holdfast is light yellowbrown or olive in color and old holdfast is dark-brown or black-brown. In cross-section, the color of the medullar layer is darker from the color of the next layer in both young and old plants.

Mucilage ducts or canals were not found in our samples. In cross-section, the juvenile blade is ca. 141-192 $\mu \mathrm{m}$ thick; medullar part occupies ca. $16.6-23 \%$ of its thickness. In fertile plants, the blade is ca. 1,650 $\mu \mathrm{m}$ thick and the medullar part occupies ca. 13\% of its thickness. Sporangial sori develop in late July-September on both sides of the blade in its lower and middle parts as wide shapeless spots with not coincident outlines at first. Upon further development, the spots outlines more or less coincide. Mature unilocular sporangia are 51-58 $\mu \mathrm{m}$ in length (Fig. 6D). Paraphyses are ca. $115 \mu \mathrm{m}$ long, narrower at the distal end (Fig. 6E).

L. inclinatorhiza is perennial, abundant and widely distributed in the Sea of Okhotsk, growing at depths of 2-25 $\mathrm{m}$ in places with different degrees of wave exposure. It typically occupies rocks and stones, but is also capable to grow on soft substrate (sand, silt). It sometimes forms local mono-species communities with a biomass of 10-12 $\mathrm{kg}$ per $1 \mathrm{~m}^{2}$ and density of $10-15$ plants per $1 \mathrm{~m}^{2}$. More often it is found as subdominant species among other kelps. 

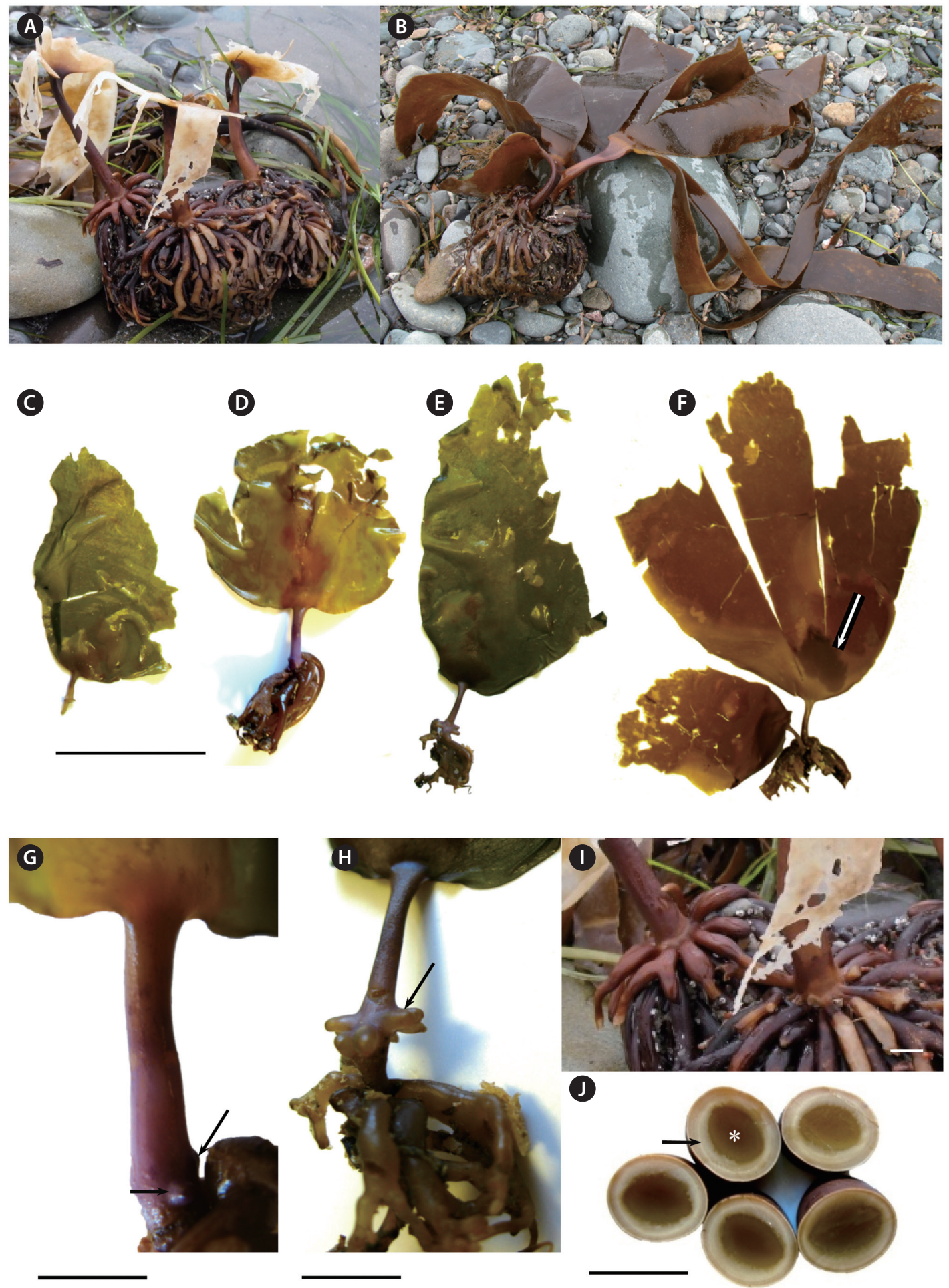

Fig. 4. Laminaria inclinatorhiza. (A, B \& I) Typical morphology (voucher $\mathrm{CH} 2207$ ). (A) The blades were fragile and easily detachable from the stipe. (B) Complete blades cast ashore. Flattened 1/3 of stipe is seen very well. (C-H \& J) Deep-water population from Taujskaya Bay (voucher CH2206). Juvenile plants at different developmental stages are shown. Note that during the stage of linear growth, the plants are more roundish and cordate in L. inclinatorhiza than in L. appressirhiza and L. digitata (C-E) and have quite thick haptera (D). Even juvenile plants had sporangial sori (F, arrow). (G \& H) Enlarged images of plants shown in Fig. 4D \& E. The stipe was characteristic lilac-violet in color. Arrows point to newly developing hapteral outgrowths, which result in multi-layered cone-shaped holdfast. (I) Enlarged image of plants shown in Fig. 4A, demonstrating very thick haptera in old plants with typical morphology. (J) Horizontal cross-section cut through the stipes of five different 2-year-old plants. The color of medullar layer (marked with asterisk) is much darker then the color of the next layer. Scale bars represent: C-F, $5 \mathrm{~cm} ; \mathrm{G}-\mathrm{J}, 1 \mathrm{~cm}$. 

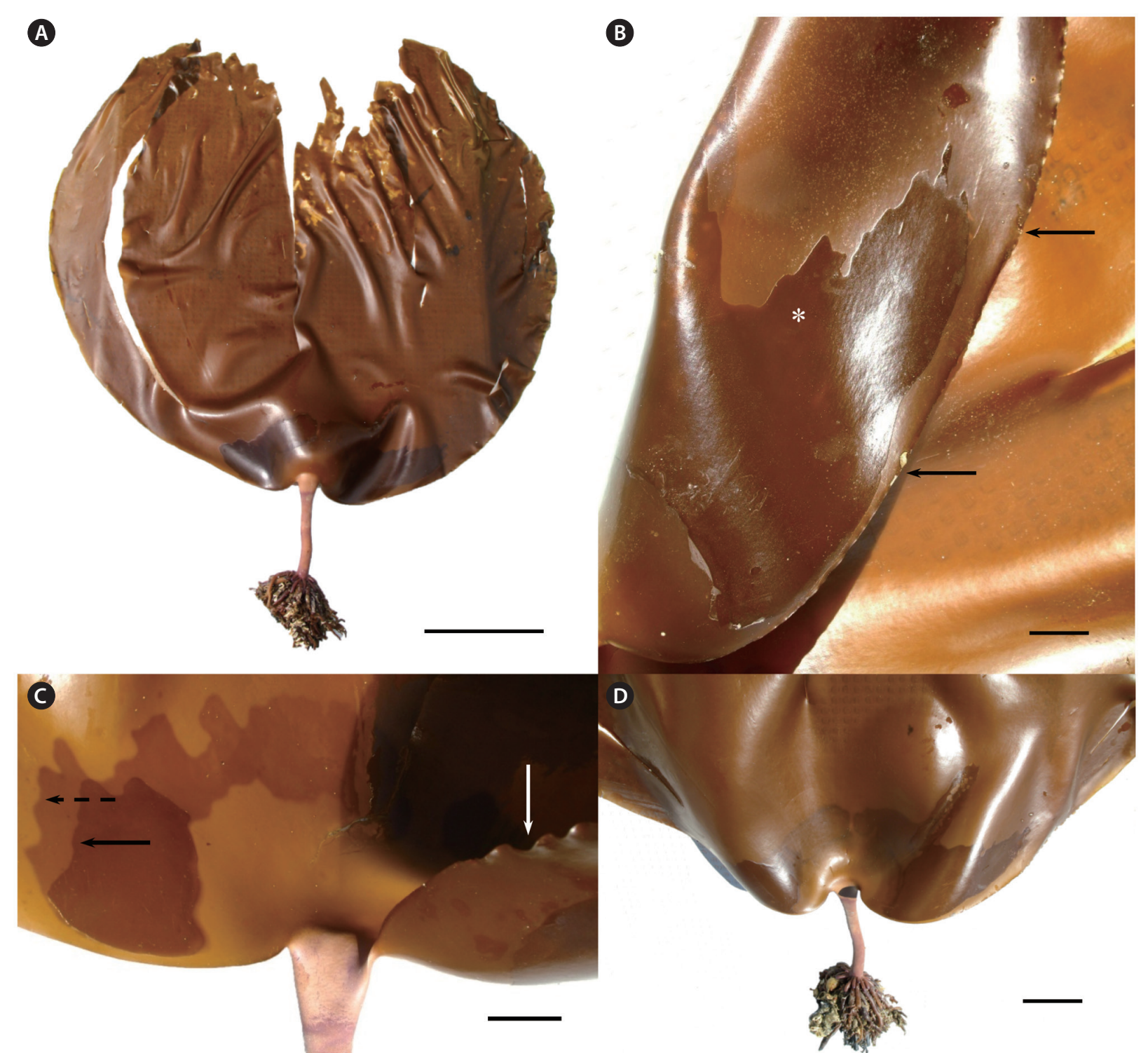

D
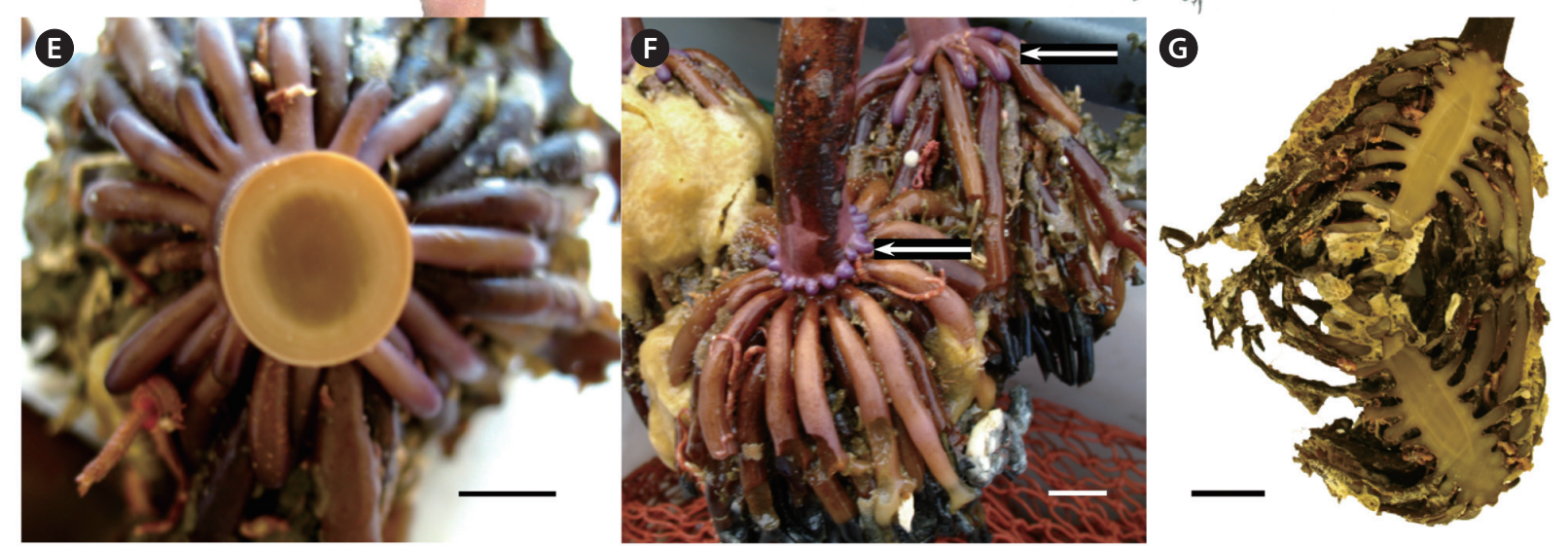

Fig. 5. Laminaria inclinatorhiza. Deep-water population from Taujskaya Bay (voucher CH2206). (A) Old plant. (B) Enlarged part of blade, showing wavy margin (arrows) and sporangial sori (asterisk). (C \& D) Blade's base is funnel shaped. Stipe is flattened below the transition zone. Black arrows point to sporangial sori not coincident on both sides of blade and white arrow points to wavy margin of the blade. (E-G) Thick cone-shaped holdfast. (F) Characteristic ring of small hapteral outgrowths of bright lilac-violet color on the top of the holdfast (arrows). (G) Sectioned holdfast, showing typical cone-like shape and multilayered haptera. Scale bars represent: $A, 20 \mathrm{~cm} ; B, 5 \mathrm{~cm} ; C \& G, 3 \mathrm{~cm} ; D, 10 \mathrm{~cm} ; E \& F, 1 \mathrm{~cm}$. 


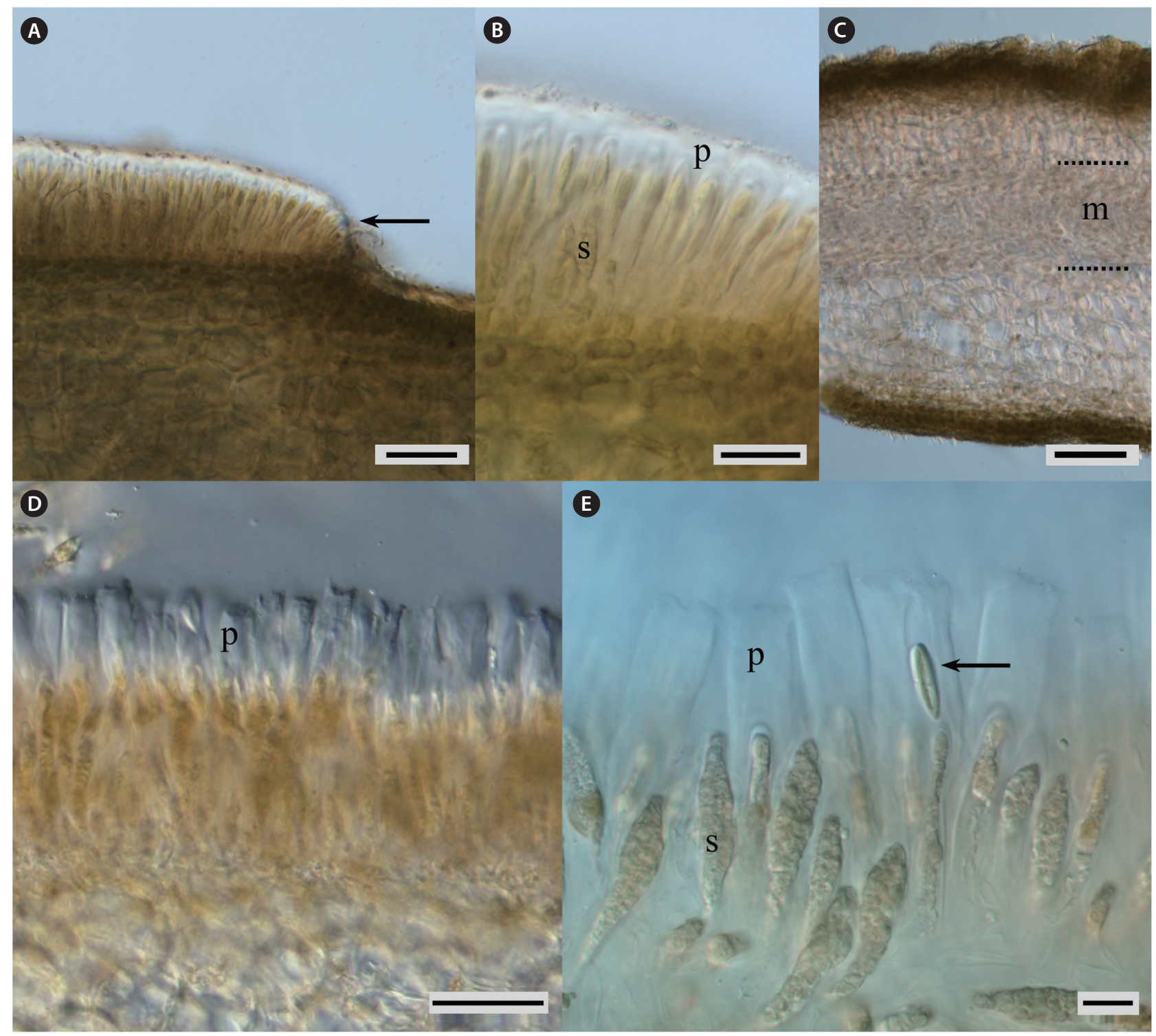

Fig. 6. Cross-sections of fertile blades of Laminaria appressirhiza (A-C) and L. inclinatorhiza (D \& E). Paraphyses of L. inclinatorhiza (D \& E) have longer gelatinous caps than in L. appressirhiza (A \& B). (A) Arrow points to a zone in the cortical layer where sporangia and paraphyses begin to develop. (C) Part of fertile blade of $L$. appressirhiza with thick medullar layer (dashed lines, $\mathrm{m}$ ). (E) Arrow points to a diatom cell, which is inside the long gelatinous cap. p, paraphyses; s, sporangia. Scale bars represent: A, B \& D, $30 \mu \mathrm{m} ; C, 100 \mu \mathrm{m} ; \mathrm{E}, 15 \mu \mathrm{m}$.

\section{Description of morphology of Laminaria in- clinatorhiza from Taujskaya Bay, Sea of Okhotsk (voucher CH2206)}

We found an unusual and interesting deep-water population of L. inclinatorhiza from the north of the Sea of Okhotsk in Taujskaya Bay growing at depths of 15-25 m on exposed rocky coasts (Figs 4C-H, J \& 5). It grew among other laminariaceaen algae, but more often it formed mono-species communities with 3-5 plants and biomass of 1.7-2.6 kg per $1 \mathrm{~m}^{2}$. Older plants (Fig. 5A) were often found growing solitary and young plants were tightly interwoven in groups of 3-7 (Fig. 4C-F). At this time, we are not convinced that this morphology presents a stable and different taxonomic form of L. inclinatorhiza. We consider it to be an ecotype that develops in deep-water areas protected from strong water movement.

In this population of L. inclinatorhiza the blade is not very dissected and is more concave in its basal part. The haptera are thick, light olive or olive in color (Figs 

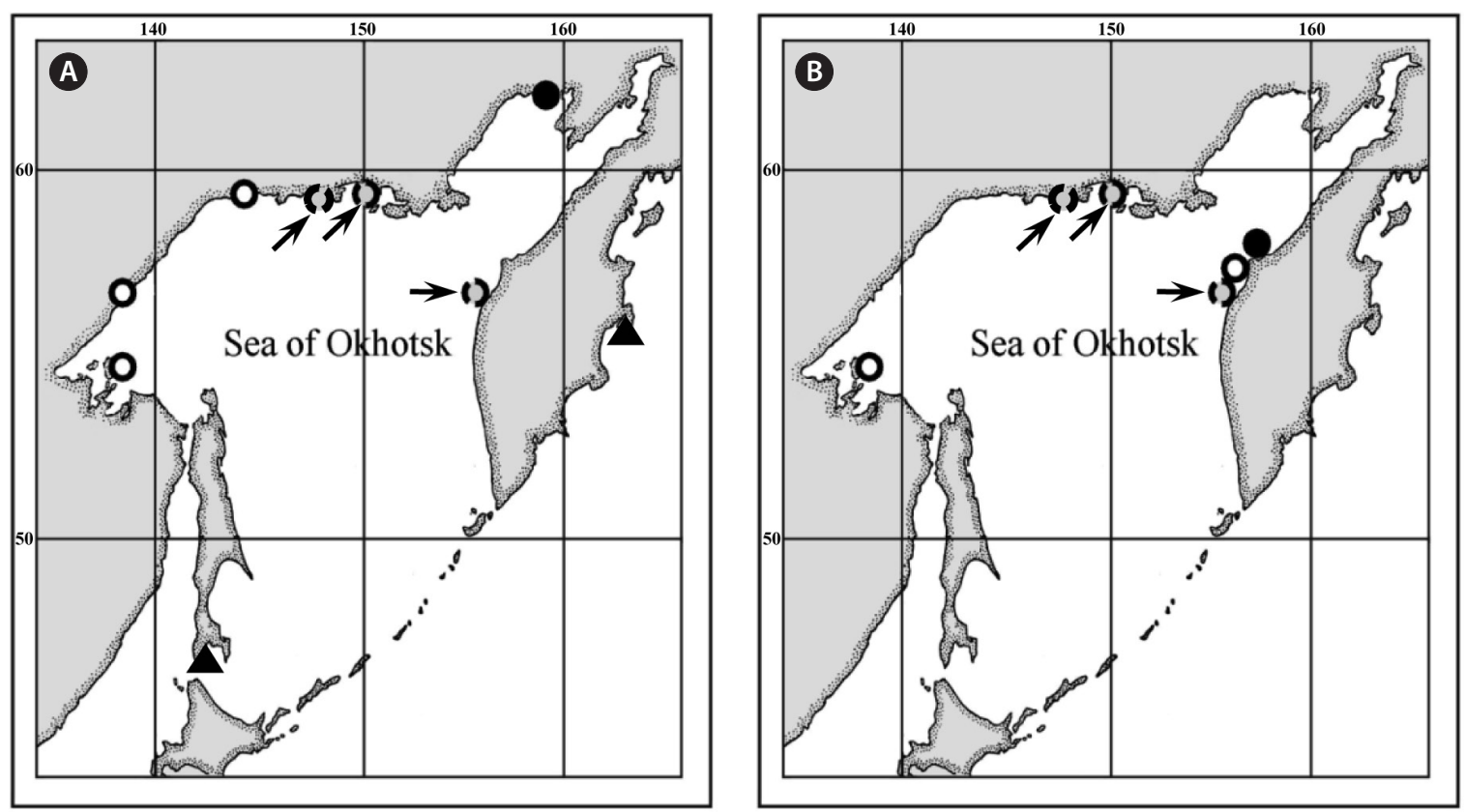

Type locality. $\quad 0$ Records of paratypes distribution from Petrov and Vozzhinskaja (1970).

$\rightarrow$ () Personal collections of present authors. $\Delta$ Records of doubtful species distribution from references.

Fig. 7. Maps of currently known distribution of Laminaria appressirhiza (A) and L. inclinatorhiza (B).

$4 \mathrm{H} \& 5 \mathrm{E}-\mathrm{G})$. The holdfast is tapered, shaped like a cone in cross-section. A characteristic ring of small hapteral outgrowths of bright lilac-violet color develop at the top of the holdfast (Figs 4G \& 5F). With further growth, the bright lilac-violet color gradually turns into red-violet. In young plants, the stipe is violet in color (Fig. 4G). In old blades, the stipe is cylindrical, thick, $1.5-1.7 \mathrm{~cm}$ in diameter and $20-25 \mathrm{~cm}$ long. Under the sea and for a short time after removal from seawater, the stipe has a characteristic white-violet or lilac color and is slightly fluorescent. Upon drying, it becomes red-violet in color and the fluorescence disappears. The upper part of stipe is flattened, slightly broadened, light or yellow-pink colored, which is very different from the coloration of the lower $2 / 3$ of stipe and the blade. The blades have no bullation at any age. Mucilage ducts or canals were not found in our samples, including young and older thalli.

Sporangial sori start to develop on both sides of blade in its lower and middle parts, forming shapeless spots that do not coincide in outline at first (Fig. 5A-D). Upon further development, the outlines of the spots more or less coincide and the sporangial tissue spreads to the blade's middle part. The juvenile $15 \mathrm{~cm}$-long plants (i.e., at early stages of development during 1st year of growth) also had sporangial tissue (Fig. 4F). We consider that the most abundant sporangial development probably occurs from late August to early September.

\section{Species distribution}

The currently known distribution of L. appressirhiza and L. inclinatorhiza is shown in Fig. 7. These species are currently considered as Okhotsk endemics. It should be noted, however, that Suhoveeva and Klochkova (1990) reported finding of a single specimen corresponding to the diagnosis of L. appressirhiza from Kamchatsky Inlet, but that single plant was floating and not attached to the substrate. The possibility that it was brought to the area (i.e., on ships or in ballast waters) cannot be ruled out (Klochkova 1998). More recently, we worked in the coastal areas of eastern Kamchatka, including Kamchatsky Inlet, and did not find Okhotsk endemics growing there. Also, L. appressirhiza was said to be a rare species with limited distribution in deep-water areas in Krillion peninsula located on the junction of the Sea of Okhotsk and Tatars Strait and influenced by deep cold water masses from the Sea of Okhotsk (summarized in Klochkova 1996). However, this distribution record needs additional confirmation because to date this species was neither recorded from the coast of eastern Sakhalin nor from the South and North Kurile Islands (e.g., Ogorodnikov 2007, Evseeva 2009). 


\section{DISCUSSION}

Our results support the existence of two digitate Laminaria species, L. appressirhiza and L. inclinatorhiza, in the Sea of Okhotsk. Morphologically, they are distinct from each other and from L. digitata. The two species are easily distinguishable by a number of morphological characteristics; L. inclinatorhiza can unmistakably be distinguished by its peculiar holdfast, which is cone-like, multilayered, very thick and massive, and L. appressirhiza has rolled margins of blades, lamellar part of thallus looking like a rosette, and sporangial sori developing only on one side of the blade. Because of the peculiar morphology of the holdfast, L. inclinatorhiza grows very well on soft substrates, such as sand and silt, which are generally not suitable for laminariaceaen algae. However, soft substrates are common on the northern coast of the Sea of Okhotsk and also predominate in western Kamchatka, where this species is distributed. To date, the known distribution of L. appressirhiza and L. inclinatorhiza is on the continental side of the Sea of Okhotsk, Shantar Islands, and western Kamchatka. Although L. digitata has a very wide distribution including both northern and southern hemispheres, it seems to be restricted only to the Atlantic Ocean and western Arctic region.

The unique macroalgal flora of the Sea of Okhotsk is due to the system of currents in the region, mosaic climatic and hydrological conditions in its different areas, and geological history, which resulted in long-term geographic isolation (Klochkova et al. 2012). To date, five brown and five red algae have been reported as endemic species of this region; the brown algae L. appressirhiza, $L$. inclinatorhiza, Pseudolessonia laminarioides (Postels et Ruprecht) Cho, Klochkova, Krupnova et Boo, Phyllariella ochotensis Petrov et Vozzhinskaja, and Tauya basicrassa Kloczcova et Krupnova, and the red algae Crossocarpus lamuticus Ruprecht, Ionia cornu-cervi Perestenko, Palmaria moniliformis (Blinova et Zinova) Perestenko, Scagelia breviarticulata Perestenko, and S. subnuda (Ruprecht) Perestenko. Some species have been reported in the floristic lists from other North Pacific islands, such as the Commander Islands (Selivanova and Zhigadlova 1997) and Pribilof Island in Alaska (Lindstrom 2006). The plant collected from Pribilof Island and identified as Phyllariella ochotensis (Lindstrom 2006) was in fact Aureophycus aleuticus Kawai, Hanyuda, Lindeberg et Lindstrom (Lindstrom personal communication). The floristic list by Selivanova and Zhigadlova (1997) should also be re-examined providing detailed comparison of two populations from both localities for each taxon in question, because the history of flora formation, hydrology, and substrates distribution in the region do not support existence of the Okhotsk endemics on the Commander Islands.

The Sea of Okhotsk and Arctic Russia were named as regions of the world still not comprehensively studied, where systematic studies remain morphologically based and there has been little recent work (Bolton 2010), i.e., phylogenetically based systematics. However, it should be emphasized that for many algal taxa distributed in these regions, including endemics and commercially important kelp species, information on morphology and anatomy and differences in the morphogenesis of species and their forms is very limited. These basic studies are essential because incomplete understanding of genusor species-specific (or species form-specific) morphology and anatomy can lead to a wrongful presumption of the existence or non-existence of a taxon. For example, Laminaria multiplicata Petrov et Suchovejeva was often cited in floristic lists of the Sea of Okhotsk based on its first record in 1976 and referred to as rare endemic species. However, detailed morphological analysis of the type and paratype specimens and long-term surveys of the type locality and proximate bays and inlets have not confirmed the existence of such entity at all (Klochkova et al. 2010). Therefore, detailed re-evaluation of previous floristic studies based on morphological and anatomical characteristics should be carried out beforehand.

In this study, we focused on morphology, anatomy, ecology, distribution and abundance of two endemic species from the Sea of Okhotsk, L. appressirhiza and L. inclinatorhiza. According to traditional morphological classification they both belong to the genus Laminaria sensu lato, looking somewhat similar to the type species of the genus, L. digitata. Morphologically, L. appressirhiza is somewhat more similar to L. digitata than L. inclinatorhi$z a$. The young plants are more roundish and slightly cordate in L. inclinatorhiza, whereas in L. appressirhiza and L. digitata they look shortly attenuate at the beginning of growth. The three species do not have bullations on the blades at any age. It should be noted that once we collected a plant of L. appressirhiza, which developed irregular alternating depressions on the top of one blade, but this looked like developmental abnormality. In our observation, L. digitata from Kongsfjorden, Svalbard grows much larger than L. appressirhiza and L. inclinatorhiza from the Sea of Okhotsk; however herbarium specimens of L. digitata from the White Sea (kept in LE, St. Petersburg) were almost the same size with Okhotsk Laminaria. Species $L$. appressirhiza and L. inclinatorhiza are perennial, as seen from counting the number of annual rings on the cross- 
sections of stipes and also from analyzing morphologies of collected plants. The oldest thalli collected by us were 3 years old; however, we do not know the maximum life span of these species. The maximum life span of L. digitata is known to be 6-10 years (e.g., Biological Traits Information Catalogue, http://www.marlin.ac.uk/BIOTIC) and $L$. hyperborea (Gunnerus) Foslie can live for more than 12 years with an average of 8 years (Kelly 2005).

Some characteristics of L. appressirhiza and L. inclinatorhiza mentioned by the original authors did not appear stable in different environments. In general, it would be fair to say that the type specimens of these species do not reflect their morphologies in details, although they depict the basic concept of both entities, which allows credible identification. Although collected 48-49 years ago, the type specimens (kept in the LE Herbarium, St. Petersburg, Russian) are in satisfactory condition.

In species diagnosis of L. appressirhiza the holdfast was said to originate at almost right angles to the stipe (Petrov and Vozzhinskaja 1970). The importance of this character was even indicated in the species name, $a p$ pressirhiza, i.e., being appressed. Although in our investigated samples the shape of holdfast was the same as originally described for this species, we do not consider this to be a stable character, since we also observed haptera branched at an acute angle in plants growing on cobble substrates. Actually, we noticed that almost all laminariaceaen algae can have haptera developing at right angle to the stipe when they grow on substrates made with large solid rocks, which they generally tend to prefer.

According to our observations and differently to what was said by Petrov and Vozzhinskaja (1970), in the plants of $L$. inclinatorhiza studied by us sporangial sori did not develop simultaneously on both sides of the blade. The sporangial sori outlines on both sides of the blade did not coincide at first and only became more or less coincident later. This difference is, perhaps, because Petrov and Vozzhinskaja (1970) have observed only mature large plants and worked with dried herbarium specimens, whereas our study included multiple fresh plants of different ages and growth stages. Moreover, as we observed in the deep-water population of L. inclinatorhiza from Taujskaya Bay, even $15 \mathrm{~cm}$-long juvenile plants, which were supposed to be in the phase of active linear growth, could develop sporangial tissue. Also, the external coloration of those deep-water plants was quite unique, as they had a ring of small hapteral outgrowths of bright lilac-violet color developing above the holdfast that gradually turned into red-violet with growth, and the stipe was characteristically white-violet or lilac color and slightly fluorescent. Altogether, this morphology seems unusual for Laminariales and its underlying reasons are currently unknown to us.

The shape of sporangial sori is not a stable morphological character and can deviate from the norm in different populations of the same species according to growth environmental conditions (e.g., Korolyova 2004, Saushkina 2006). Saushkina (2006) studied changes in the reproductive strategies of laminariaceaen algae in Kamchatka under unfavorable environmental conditions and reported that even $<1^{\circ} \mathrm{C}$ difference in seawater temperature can significantly influence monthly seasonality and speed of spore formation. In the areas experiencing high levels of anthropogenic pollution, sporogenesis deviates from the norm. It should be noted, however, that Taujskaya Bay in the Sea of Okhotsk is a clean area, thus sporogenesis in the juvenile plants of L. inclinatorhiza was not related to pollution and occurred due to another factors, which we do not precisely know. Normally development of sporangial sori should occur only in physiologically mature tissue and also spores do not develop in the zone, which ensures active linear growth of the plant (meristem). The fact that those juvenile blades of L. inclinatorhiza from Taujskaya Bay already reached sufficient maturity to initiate reproduction is interesting. What we consider as stable characters that under normal environmental conditions sporangial sori develop on one side of the blade in L. appressirhiza and on both sides in L. inclinatorhiza and localize in the lower part of the blade and later distribute to its middle part. In L. digitata, sori are produced over most of the blade surface, except the most distal or proximal areas, all year round with maxima in July-August and November-December (e.g., Biological Traits Information Catalogue). Also, we observed that the presence of mucilage ducts is not a stable morphological character in two Okhotsk species. Petrov and Vozzhinskaja (1970) indicated the presence of large mucilage ductc in the blades of both species. However, we did not find mucilage ducts or canals in our plants of $L$. inclinatorhiza, including young and mature fertile blades. In young plants of $L$. appressirhiza, the mucilage ducts were present on both sides of the blade; however, in the fertile blades, they appeared only on one side that did not have sporangial sori. Kasahara (1985) studied development of mucilage canals and mucilage glands in two species of Laminaria sensu lato, L. angustata Kjellman and L. yezoensis, and reported that occurrence of these structures correlated with the plant age and were probably temperature and light dependent. Moreover, the mucilage canals were absent in some parts of the blade and present in another. Petrov (1972) also 
indicated that mucilage ducts in the stipe and haptera could be present or absent in the same Laminaria species growing in different environments and thus could not be used as stable morphological characters. Thus, in different populations of L. appressirhiza and L. inclinatorhiza mucilage ductc might also be present or absent and thier localization varies with plant age.

In conclusion, our new data extend the knowledge on two commercially important laminariaceaen algae from the Sea of Okhotsk and highlight the need for further studies on the biology of development and reproduction of other macroalgal species in this area.

\section{ACKNOWLEDGEMENTS}

We thank member of the Editorial board of 'Novosti Sistematiki Nizshih Rastenii' (News on Systematics of Non-vascular Plants, St. Petersburg, Russia), Dr. Rinat M. Gogorev, for permission to use verbal translation of the diagnosis published in Petrov and Vozzhinskaja's paper (1970) and curator of algal herbarium in Komarov Botanical Institute of Rus. Acad. Sci. (St. Petersburg, Russia), Dr. Tatyana A. Mihailova, for her kind help in providing us scanned images of type specimens. The expedition in the Sea of Okhotsk was organized and supported by MagadanNIRO. This research was partially supported by a grant from Extreme Genomics Program funded by Ministry of Land, Transport and Maritime Affairs of Korean Government to G. H. Kim. This research was also partially funded by a grant from National Research Foundation of Korea (NRF 20120006718) to G. H. Kim.

\section{REFERENCES}

Bartsch, I., Wiencke, C., Bischof, K., Buchholz, C. M., Buck, B. H., Eggert, A., Feuerpfeil, P., Hanelt, D., Jacobsen, S., Karez, R., Karsten, U., Molis, M., Roleda, M. Y., Schubert, H., Schumann, R., Valentin, K., Weinberger, F. \& Wiese, J. 2008. The genus Laminaria sensu lato: recent insights and developments. Eur. J. Phycol. 43:1-86.

Belij, M. N. 2011. Species composition, peculiarities of distribution of macroalgae in the northern area of the Sea of Okhotsk, and their role as a substrate for spawning of herring. Dissertation of Candidate of Biological Science, MagadanNIRO, Magadan, Russia, 174 pp (in Russian).

Biological Traits Information Catalogue. Available from: http://www.marlin.ac.uk/BIOTIC. Accessed Mar 28, 2012.
Blinova, E. I. 1968. Seaweeds of the northeastern part of the Sea of Okhotsk. Novosti Sistematiki Nizshih Rastenii (News on Systematics of Non-vascular Plants) 5:33-38 (in Russian).

Bolton, J. J. 2010. The biogeography of kelps (Laminariales, Phaeophyceae): a global analysis with new insights from recent advances in molecular phylogenetics. Helgol. Mar. Res. 64:263-279.

Evseeva, N. V. 2009. Macrophytobenthos of the coastal zone of the South Kurile Islands: species composition, distribution, and resources. Dissertation of Candidate of Biological Science, VNIRO, Moscow, Russia, 172 pp (in Russian).

Guiry, M. D. \& Guiry G. M. 2012. AlgaeBase. World-wide electronic publication, National University of Ireland, Galway. Available from: http://www.algaebase.org. Accessed Mar 28, 2012.

Kasahara, K. 1985. On the mucilage canal and the mucilage gland in two species of Laminaria (Phaeophyceae, Laminariales). Bot. Mag. Tokyo 98:29-40.

Kelly, E. 2005. The role of kelp in the marine environment. Irish Wildlife Manuals, No. 17. National Parks and Wildlife Service, Department of Environment, Heritage and Local Government, Dublin, Ireland. Available from: http://www.npws.ie/. Accessed Mar 28, 2012.

Klochkova, N. G. 1996. The marine algae flora of Tatars Strait (Sea of Japan) and peculiarities of its formation. Dalnauka, Vladivostok, 292 pp (in Russian).

Klochkova, N. G. 1998. An annotated bibliography of marine macroalgae on Northwest coast of the Bering Sea and the Southeast Kamchatka: the first revision of flora. Algae 13:375-418.

Klochkova, N. G. \& Berezovskaya, V. A. 1997. The seaweeds of Kamchatka's shelf: biology, distribution, chemical composition. Dalnauka, Vladivostok, 153 pp (in Russian).

Klochkova, N. G., Korolyova, T. N. \& Kusidi, A. E. 2009. Atlas of marine algae of Kamchatka and surrounding areas. Vol. 1. KamchatNIRO Press, Petropavlovsk-Kamchatsky, 216 pp (in Russian).

Klochkova, T. A., Kim, G. H., Lee, K. M., Choi, H.-G., Belij, M. N. \& Klochkova, N. G. 2010. Brown algae (Phaeophyceae) from Russian Far Eastern seas: re-evaluation of Laminaria multiplicata Petrov et Suchovejeva. Algae 25:77-87.

Klochkova, T. A., Klochkova, N. G., Belij, M. N., Kim, H. -S \& Kim, G. H. 2012. Morphology and molecular phylogeny of Chordaria okhotskensis sp. nov. (Ectocarpales, Phaeophyceae) from the Sea of Okhotsk. Cryptogam. Algol. 33:3-20.

Korolyova, T. N. 2004. Development of the brown alga, Laminar- 
ia bongardiana $\mathrm{P}$. et R., in Kamchatka area and surrounding waters. Dissertation of Candidate of Biological Science, Moscow State University, Moscow, Russia, 185 pp (in Russian).

Lindstrom, S. C. 2006. Biogeography of Alaskan seaweeds. J. Appl. Phycol. 18:637-641.

Ogorodnikov, V. S. 2007. Macroalgae of the northern Kurile Islands. Dissertation of Candidate of Biological Science, KamchatGTU, Petropavlovsk-Kamchatsky, Russia, 174 pp (in Russian).

Petrov, Yu. E. 1972. Systematics of some species of the genus Laminaria Lamour. from the Far East. Novosti Sistematiki Nizshih Rastenii (News on Systematics of Non-vascular Plants) 9:47-59 (in Russian).

Petrov, Yu. E. \& Vozzhinskaja, V. B. 1970. New species of the genus Laminaria from the Sea of Okhotsk. Novosti Sistematiki Nizshih Rastenii (News on Systematics of Nonvascular Plants) 7:81-87 (in Russian).

Ruprecht, F. J. 1850. Algae ochotenses. Die ersten sicheren Nachrichten über die Tange des Ochotskischen Meeres. Buchdruckerei der Kaiserlichen Akademie der Wissenschaften, St. Petersburg, 243 pp.

Saushkina, L. N. 2006. Peculiarities of morphology of the brown alga, Laminaria bongardiana P. et R., in connection with its growth, reproduction, and environmental conditions. Dissertation of Candidate of Biological Science, KamchatGTU, Petropavlovsk-Kamchatsky, Russia,151 pp (in Russian).

Schapova, T. F. 1948. Geographic distribution of the members of Laminariales in the northern part of the Pacific Ocean. Trudi Instituta Okeanologii (Works of the Institute of Oceanography) 2:89-138 (in Russian).

Selivanova, O. N. \& Zhigadlova, G. G. 1997. Marine algae of the Commander Islands. Preliminary remarks on the revision of the flora. III. Rhodophyta. Bot. Mar. 40:15-24.

Sinova, E. S. 1954. Algae of the Okhotsk Sea. Trudi Bot. Inst. Akad. Nauk S. S. S. R. 2:259-310 (in Russian).

Suhoveeva, M. V. \& Klochkova (Kloczcova), N. G. 1990. Additions to the marine algae flora of eastern Kamchatka. Novosti Sistematiki Nizshih Rastenii (News on Systematics of Non-vascular Plants) 27:40-48 (in Russian).

Vozzhinskaja, V. B. 1965. Marine algae of the western coast of Kamchatka. Novosti Sistematiki Nizshih Rastenii (News on Systematics of Non-vascular Plants) 2:73-77 (in Russian).

Zambounis, A., Gaquerel, E., Strittmatter, M., Salaün, J. -P., Potin, P. \& Küpper, F. C. 2012. Prostaglandin $\mathrm{A}_{2}$ triggers a strong oxidative burst in Laminaria: a novel defense inducer in brown algae? Algae 27:21-32. 